\title{
ФІЛОСОФСЬКО-СВІТОГЛЯДНІ АСПЕКТИ УКРАЇНСЬКИХ ПРАВОВИХ СИСТЕМ. ФЕНОМЕН ПИЛИПА ОРЛИКА
}

\begin{abstract}
А.К. Бичко
Однією з причин тих складностей та суперечностей, з яких не може вийти Україна, є, на мій погляд, недостатньо сформульована концепція свідомості нації. Зрештою, це, певною мірою, цілком закономірно. Не пройшовши так би мовити процедури люстрації, в Україні були створені всі умови для розкрадання народних багатств і збереження достатньо ворожого щодо нації кадрового складу державного управління. Можна від усієї душі поспівчувати тим вчорашнім активним провідникам партійної програми та їхнім найактивнішим комсомольським помічникам, які все життя «боролися з українським націоналізмом» в усіх його проявах, і раптом опинилися в ролі захисників цього націоналізму. Адже школа, яку вони пройшли в ролі партійних та комсомольських діячів, була для них зрозумілою і виробила в них уміння змінюватися «разом з лінією партії, тобто керуватися лише одним принципом - вигоди для себе. Всі навики пристосовництва дуже знадобилися в тяжкі хвилини переходу від однієї системи до іншої і поставили їх поза конкуренцією щодо щиросердних, але не таких, що пройшли школу організаторської діяльності, націоналістичних патріотів, які цілком щиро, але невміло намагалися сприяти становленню незалежної та самостійної нової держави - України, що нарешті вийшла з-під колоніального гніту, в якому вона перебувала близько 700 років (починаючи з часів татаро-монгольської навали). Саме колонізоване становище виробило такі ментальні риси в нації, як слухняність щодо ролі «повелителя і господаря», прагнення йому прислужитися,
\end{abstract}


покірність і намагання всіляко заслужити його милість. Інакше кажучи, горда, героїчна (згадаймо хоча б козацтво), глибоко освічена нація, перетворюється в націю прислужників та лакеїв. Цьому особливо сприяв той факт, що протягом сторіч колонізатори всіляко «всмоктували» інтелект нації- українську шляхту на межі XVI-XVII сторіч забрала Польща, в XVIII-XIX ст. ця шляхта збагатила і практично створила культурні цінності Росії. А ще в давній Греції існувала думка - «Якщо мислителя убити, то його ідеї відроджуються в третьому поколінні». Знищений інтелектуальний потенціал нації в 20-30-х роках XX ст. (як відомо, було розстріляно та замордовано в радянських концтаборах близько 80\% інтелігенції України), таким чином, лише в наші дні почав відроджуватися. Слід врахувати і той факт, що в ХХ ст. Україна пережила особливо трагічні події. Дивно, як нація все ж вставала. Адже, переживши розруху 1917-1922 років, коли революція та Перша світова війна повністю знищили господарський потенціал (навіть землю, як відомо, вивозили з України), менш ніж за 10 років (1932-1933) падає на українців голодомор, і ще через 8 років починається черговий етап тотального знищення життя українців протягом 5ти років Другої світової війни. Тому, що народ підіймався, відроджувався з «попелу», мабуть, сприяло те, що століттями виробилися певні методи виживання.

Всі ці несприятливі умови, як бачимо, не знищили націю, яка в наші дні нарешті отримала право на власну долю. Неприємно, але можна зрозуміти, чому досі ще не позбавилися українці пристосовницької психології, найяскравішим виразником якої є орієнтація не на себе, а на допомогу якогось чужого «доброго пана». Це яскраво проявляється як у зовнішній політиці держави, так і в самій свідомості переважної більшості громадян нашої країни, орієнтованих не на власні сили в досягненні як матеріальних, так і духовних благ, а на «милість» держави (60\% в державі так званих «льготників»), на вміння «вирвати» ці блага, хабарництво. В цих умовах цілком закономірними є такі явища, як хабарі, корупція в більших чи менших розмірах.

На жаль, затримці процесу становлення національно-державної самосвідомості сприяе той факт, що починаючи з діяльності міністерства освіти, не говорячи вже про міністерство культури, яке звело культуру до сфери лише мистецтва, практично зроблено надзвичайно мало для розвитку національно-державної самосвідомості. Іноді в найгіршій формі (найтиповішим показником цього є всіляка підтримка діяльності «співаючого ректора» Поплавського) зведені до мінімуму гуманітарні знання. А якщо врахувати той факт, що людина - це гуманітарій 
в першу чергу (в сім`ї, в спілкуванні з іншими людьми, в політиці, в економіці, коли від її совістливості і відповідальності, і навіть від громадянсько-патріотичної спрямованості, залежить весь трудовий процес і т. ін.), то незнання найпростіших морально-етичних норм (адже, етика знята, як предмет у вищих учбових закладах, а філософія в цілому зведена до 30-16 годин) не може сприяти формуванню гідного громадянина молодої держави.

А ті спроби заповнити духовний вакуум - насадження через засоби масових комунікацій жорстокості та насильства; активна пропаганда «футбольної лихоманки»; намагання звести всі духовні цінності лише до релігійних ідей, які дійсно свого часу - в XV-XVIII ст., були виразниками національного духу; хворобливе смакування трагічних фактів історії українського народу - не сприяють становленню сучасних національно-державницьких орієнтацій.

Значно продуктивнішим, на мій погляд, є інший шлях. Це виділення та акцентування сфери колосальних позитивних цінностей, які були вироблені і внесені до світової культури українським народом протягом тисячоліть.

Однією з таких незаперечних цінностей є система правових ідей, вироблених народом, що завершилося створенням першої у світі Конституції 1710 p.

Звичайно, факт створення цієї Конституції є надзвичайно важливим, але це було лише завершення тривалого шляху розвитку правових ідей, вироблених українським народом протягом століть, що, в свою чергу, стали однією із форм складного процесу формування національної самосвідомості українців.

Головним змістом цієї самосвідомості, вираженої в правових ідеях, є те, що лише у XVIII ст. висловлено в Декларації прав людини та громадянина, прийнятій Установчими зборами Франції 4 серпня 1789 р., коли основною цінністю було проголошено права кожного суб'єкта права, кожної людини.

I якщо в Конституції Пилипа Орлика 1710 р. досить детально обгрунтовані ці права, то, починаючи з ранніх писаних пам'яток українського права, вони вже достатньо представлені. Першою писаною пам'яткою права, як відомо, була «Руська правда» (XI ст.), яка містить в собі статті, що носили на той час яскраво виражений гуманістичний характер. Так, якщо в Статуті князя Ярослава, написаному близько першої половини XI ст., законодавчо закріплюється звичай кровної помсти - «убитого не можна помилувати, тому що зло повинно бути відплачено злом», то в «Руській правді» відзначається: «Після Яросла- 
ва зібралися сини його: Ізяслав, Святослав, Всеволод і воєводи їхніКоснячко, Переніг, Никифор і відмінили кровну помсту, а встановили за вбивство кунами відкупитися» [2, с. 19]. Таким чином ліквідована в XI ст. смертна кара.

Високий рівень взаємоповаги, самосвідомості зафіксований в ряді статей. Так, за образу гідності виписані покарання: «Якщо хтось вдарить мечем, вийнявши його, або рукояткою, тоді оплачує 12 гривень збитів за обіду» $[4$, с. 15$]$ - «Якщо вийняв меч, але не вдарив, то гривна кун» [4, с. 223].

Гуманістична спрямованість «Руської правди» чітко виражена і у ставленні до прав жінки. Адже і в грецькому, і в римському, і в старонімецькому праві жінка трактується як власність чоловіка. Згодом в феодальній Європі у неї були лише дві долі-або заміжжя по волі батька, або ж монастир. При цьому доньки були виключені з поділу спадщини.

На сторінках же «Руської правди», жінка після смерті чоловіка стає главою сім'ї, вирішувала долю як синів, так і доньок. Зафіксовано право захищати матір проти сваволі дітей: «Дітям волі не давати». За вбивство жінки покарання було таким же, як і за вбивство чоловіка.

В «Руській правді» достатньо чітко проявилися такі характерні особливості української ментальності, як толерантність, орієнтованість на ідею кожної неповторної особистості, моральна вимогливість. Цікавим щодо цього є стаття, в якій рекомендується прискіпливо перевіряти вірогідність будь-яких свідчень: «Вивідайте у винуватця все достовірно, але спершу довідайтесь про життя наклепника. I коли благопорадник і благовірник віднайдуться, то також не йміть їм віри, бо беззаконними є такі свідчення, а тому знайдіть інших свідків посоромленого, і єдина вимога: хай перед двома чи трьома свідками правдивим стане кожне слово» [4, с. 217].

Мимоволі напрошується аналогія зі значно пізнішими нормами, які були введені в Росії з часів царя Олексія (батька Петра I) «Тішайшого» і до XVII ст., коли селяни розглядалися як поміщицька власність. «Например, - пише відомий російський історик М.М. Покровський, - если должен был помещик, отвечали его крестьяне. Неисправных должников ставили на правеж, т.е. били палками каждый день, пока они не отдадут долг. Так вот за помещика ставили на правеж его крестьян, так же как раньше этой участи подвергались холопы» [10, с. 58-60].

Як бачимо, і мови не може йти про людську гідність та цінність. I протилежне ми бачимо в «Руській правді», яка дійшла до нас в 106 списках. В своїх варіантах (короткій, широкій, середній редакціях) 
«Руська правда», спираючись на звичаєве право українців, достатньо повно відтворюе основні правові принципи, починаючи з X-XI ст., записані в XI-XII ст. і діяла до XVI ст.

Принципи, закладені в ній, були продовжені в Литовському статуті, в його трьох редакціях $(1529,1568,1588)$. Дійсно, цей Статут був продовженням «Правди», тому всі вище перелічені редакції були зроблені руською, тобто тогочасною українською, мовою. Згодом текст Статуту був перекладений та надрукований вперше польською мовою в 1619, 1623, 1642, 1648, 1693 готичним шрифтом, а в 1744, 1748, $1819-$ латинським.

До Статуту ввійшов ще один правовий кодекс - так зване «Магдебурзьке право», яке сформувалося в XIII ст. Детально про це розповідає польський історик Морачевський, автор славнозвісних «Старожитностей польських». Відзначивши, що з XIII ст. відбувається активний процес формування міст, він пише: «Перші Сакси, що поселилися біля Мюнстера, Падеборна, Лейндена, з IX ст. покорили слов'янські землі і в XIII ст. панували над Сілезією по всій лівій стороні Одеру, а також біля гирла цієї річки і по правій стороні, тобто в західній Померанії. Генріх Птицелов, з роду князів саксонських, був обраний королем німецьким і потім став західнонімецьким імператором. Тому Сакси бували в Італії. Оттон Великий рівною мірою управляв у Римі, як і на Ельбі. Він підпорядкував папу та різних італійських князів своїй владі. В його часи Італія почала підіймати голову з пожарищ та руїн, відроджувалися знову старі римські міста, які в короткий час досягли влади. Оттон Великий заснував, за образом та відповідно до римських звичаїв, на Салі, Ельбі та Одері, саксонські міста. 3 часом міста досягли квітучого стану. Перша ідея їх права взята в італійців, змішавшись зі слов'янськими. Шляхтич Єпко з Рендова у період з 1215 по 1235 рр. зібрав різні статути Вестфалії, Фізії, Брандербургії, Лузани та інших провінцій, які на той час називались Саксонією. Брандтке думає, що різні статути всіх цих провінцій мали своєю основою франконське право, яке, мабуть, і в Польщу, як до німців, проникло. Це франконське право виявилося не таке, що склалося переважно через практику в Магдебурзі, звідки з магдебурзькими змінами воно дуже швидко перейшло і в Польщу і з того часу під своєю власною назвою було ледве відомо. Як би то не було, ті збірники законів, які склав Єпко із Рендова, отримали назву Sachsenspiegel, що будучи присвяченим урядовій організації, швидше всього було правом публічним. Тим часом в судах склалося право громадянське та право кримінальне. Miсто Магдебург списало свої права в одну книжку і назвало її Weichbi- 
ld. Це слово означало святий образ, а такі образи ставили на кордонах округів, тому воно означало і місто зі своїм округом. Sachsenspiegel та Weichbild склали право німецьке, тевтонське, або ж Магдебурзьке в Польщі» [5, с. 38].

Магдебурзьке право установлювало право вибору місцевого самоврядування, купецьких об'єднань, ремісничих цехів, судових органів, що здійснювалося шляхом створення місцевої муніципальної влади з колегіальною системою: кожна гміна (тобто «ця влада») обирала собі урядників для адміністрації, для керівництва прибутками та витратами і для відправлення суду. Все це сприяло розвитку громадянської свідомості, індивідуальності як такої.

Сформульоване в Німеччині в 1257 р., в Україні Магдебурзьке право поширюється в XV-XVI ст. - в 1497 р. у Львові, Лубнах, Кременці, Володимирові-Волинському, Вінниці, Житомирі, Бердичеві, Чернігові, Полтаві, Ніжині, Глухові, Гадячі та інших містах - в XV-XVI ст. При цьому Магдебурзьке право не діяло, так би мовити, в чистому вигляді. Завжди враховувалися місцеві звичаї, хоча статті, які стверджували особисту відповідальність кожного громадянина міста, цитувалися і використовувалися в суді. Так, професор М.Ф. ВолодимирськийБуданов відзначав, що у створенні сім'ї, і у розлученні чоловіка з жінкою вирішальне значення відігравав договір, який вносився в магістратські книжки, а не вінчання в церкві. Тим самим підкреслювалося вирішальне значення внутрішньої згоди, домовленості між особистостями, а значить, провідної ролі індивідуальної волі кожної людини зокрема. Всі вищеозначені правові норми і були кодифіковані та упорядковані в Литовському Статуті, який фактично діяв на землях України до 40-х років XIX ст.

Якщо врахувати той факт, що були широко використані принципи звичаєвого права, яке спиралося на моральні норми, то стає зрозумілою та основна позиція, що визначала правові норми - «старини не рушимо, новини не вводимо». Інакше кажучи, змістовний акцент випадає саме на морально-етичні норми, що відображали зміцнення індивідуально-суб'єктивної складової суспільного життя. У першу чергу це виражалося в тому, що була введена однакова кара за вбивство як шляхтича, так і простолюдина, багато уваги приділяється покаранню за образи честі та гідності людини - образливим словом, побиттям ломакою або іншим предметом, пораненням руки, ноги, ока, носа, губ, вибиттям зубів. Суспільно-небезпечними злочинами вважалися неповага до батьків, насильницький шлюб, гвалтування, порушення норм моралі щодо сім'ï, церкви. При цьому в законодавстві враховувалися 
вікові особливості злочинника та жертви злочину, проведено чіткий поділ між навмисним і ненавмисним злочином, відображена в статтях Статуту турбота про захист природи - покарання за знищення греблі, гаток, спалювання млина і навіть порушення соколиних та лебединих гнізд, пташиних принад у вигляді штрафів. Надзвичайно важливою стороною традицій українського права був той факт, що воно з самого початку було певною мірою відокремлено від теологічно-християнського тлумачення, що було характерно як для західноєвропейської культури, так і для ісламської, в якій воно так і не відокремилося закони шаріата і по сьогоднішній день $є$ провідними в мусульманських країнах.

У зв'язку зі світськістю (профанністю) правової орієнтації, українська правова думка була «прониклива» для будь-яких впливів. Опинившись у ролі провідника домінуючих культурницьких впливів на ранньому періоді формування могутньої держави - Великого князівства литовського, коли литовці складали ще племінне утворення (ятвяги, пруси, аукштайтці, сувалкійці, дзукійці), що не мало ні писемності, ні міст, саме вихідці з розгромленої Київської Русі принесли з собою ці форми духовного життя, навіть прилучили їх до православ'я. Виробляється особлива толерантна культура, де литовський субстрат складав біля $5 \%$ населення, всі інші - це були українці та білоруси. I коли 36-літній Великий князь литовський Ягайло (бл. 1350-1434) одружився з 12-тньою дочкою польського короля Людвіга Угорського, Ядвігою (1374-1399), королевою польською (обраною на сеймі польської шляхти у Сераді в 1383 р.), українські землі, в першу чергу Галичина, потрапляють до складу Речі Посполитої (яка утворилася внаслідок об'єднання Корони Польської та Великого Князівства Литовського (Люблінська унія 1569 р.).

Не вдаючись в деталі 400-х з лишнім років перебування України в складі як Литви, так і Речі Посполитої, слід відзначити той позитивний факт щодо становлення правових ідей нашого народу, що це перебування було разом з тим прямим входженням в західноєвропейські правові системи. При цьому слід згадати той факт, що в XVI ст. з'являються філософсько-правові системи італійця Н. Макіавеллі (1469-1527) та юриста і публіциста француза Ж. Бодена (1530-1596). Вперше сформульовано світське вчення про державу та права людини. Слід відзначити, що і Макіавеллі, і Боден проголошують не стільки правовий, скільки політичний суверенітет. Зрештою, це було певною мірою завершенням досить тривалого процесу. Ще в Марсилія Падуанського (бл. 1275-1333), прибічника аверроїзму, ідеолога нового ста- 
ну - «бюргерства» - є концепція про відмову від домінуючої ідеї божественного походження права, яке, мовляв, дано людині Богом. Він перший підняв питання про розмежування духовної і світської влади. У своїй праці «Захисник миру» стверджує, що право, як і держава, створюється суспільними стосунками між громадянами всіх в рівних правах (крім дітей, жінок, рабів та іноземців).

Марсилій Падуанський був першим, хто визначив, що право покликане до керівництва державою. Ще далі пішов англійський філософсхоласт Вільям Оккам (1285-1349), який був пристрасним прихильником природного права і різко виступав проти посягань римського папи на право.

Отже, уже в середні віки формується ідея правового народного суверенітету. Політичний мислитель та канцлер Флорентійської республіки Колюччо Салютаті (1331-1406) проголосив ідею громадянської рівності перед законом; Жан Боден (1530-1596) закликав до ствердження свободи віросповідання, яка, мовляв, буде сприяти стабільності держави; Гуго Гроцій (1583-1645) стверджує необхідність довіри до народу, яка, в свою чергу, є шляхом до взаємної симпатії між людьми, що повинна всіляко підтримуватися правовими нормами, спрямованими проти насильства.

Європейські правові ідеї достатньо помітно проявилися в українській бароковій культурі. Тим більше, через те, що постільки в Україні не було своїх власних вищих учбових закладів, то юнацтво України, як і Білорусії отримувало знання в західноєвропейських університетах. Адже вже до кінця XIII ст. там було 65 університетів. Із них в Італії25, в Чехії - 4. Так формується складна мозаїка бароко. В Україні воно було особливо складним, адже в ньому поєднувалися елементи латинсько-католицької, православної церковних культур з національними. Таким чином загальнолюдські мотиви поєднувалися з національними, взаємно збагачуючи один одного. Так, в орнаментальному мистецтві дерев'яне, покрите позолотою різьблення навколо ікон, у вівтарях та іконостасах сповнюється світськими елементами в різних формах рослинних, геометричних та тваринних мотивів. I в музиці в XV-XVI ст. поряд з церковними розвиваються і світські форми - партесний спів, напівдуховні, напівсвітські твори - псалми та канти, історичні думи, з'являються перші рукописні ноти, друковані підручники з теорії музики. 3 розвитком освіти посилюється інтерес до наукових, так званих гуманітарних (тобто створених людським розумом) - астрономічних, медичних, географічних, геодезичних та інших знань. У свою чергу, посиленню інтересу до науки сприяло зростання кількості бібліотек. 
У XVI ст. виникли великі книгозбірні в Острозі та Львові, в XVII ст. до них прилучилася Києво-Могилянська академія, з'являються значні бібліотеки у заможних шляхетських родинах, козацьких старшин, при монастирях, у духовенства, в різних школах.

I, звичайно, одними з основних, що поширювалися в Україні, були знання, які так чи інакше були пов'язані з проблемами національної ментальності. А це, в першу чергу, проблеми державності, права. Цілком зрозуміле є це зацікавлення. Адже українці опинилися в центрі перетинів різних національних держав - татарсько-турецької, польської, російської, кожна з яких намагалася перетворити українців на слухняних та покірних виконавців волі чужинців. Але цей натиск, як це часто буває, викликав активний спротив. Цей спротив проявив себе як зверху - в сферах української інтелігенції, так і знизу - серед народних мас. Саме ці дві сили і зливаються в такому соціальному явищі, як козацтво. Його сила і могутність в першу чергу були пов'язані, на наш погляд, з тим, що воно було фактично породжене саме інтелектуальним потенціалом українців. Так, вождями козацтва були ті, які отримували освіту як в братських школах, так і в Єзуїтських коледжах і нерідко в університетах Західної Європи. Як зазначає М. Грушевський - творцями націй були в основному або воїни, або поети. Українцям поталанило, творцями національного самоусвідомлення були два брати - поет і перекладач Дем'ян Наливайко (?-1627) і знаменитий козацький провідник - Северин Наливайко (1560?-1597). Тому значного поширення набувають ідеї національної державності, розроблені діячами українського бароко, так званими письменникамиполемістами. Найпослідовніше ці ідеї виразило два діяча - Йосип Верещинський (?- 1599) та Станіслав Оріховський (1515-1567). Прослухавши лекції в 12 університетах Європи протягом 17 років, Станіслав Оріховський в своїх працях спирається на світові досягнення державницько-правової думки. Звичайно, він підтримує найпоширенішу концепцію тогочасного вчення про державність - необхідність єдинодержавної влади короля. I тут починається відхід від загальноприйнятої концепції-Оріховський відстоює думку про необхідність виборності глави держави. 3 одного боку, це відповідає традиціям, які склалися в Речі Посполитій, а з другого, що для нас особливо важливо, це те, що виборність є головним принципом національної української традиції. Основою ж цього принципу є особиста свобода. «Якщо хтось із якогось князівства буде за те на мене гніватись, нехай тоді гнівається не на мене, а на всіх давніх теологів, а зокрема, греків, котрі говорять: „Тепер правитель цього світу виганяється геть“, а біду з неволею на князівства 
покладають. Нехай хтось тих старих філософів і ораторів за те лає (а не мене), які варварами звали людей лише за те, що люди в невільних державах мешкають. Якщо тої певної догани хочуть уникнути наші сусіди, Литва (чого я їм сердечно зичу), то хай звернуться до ясності свободи... Заяче серце в неволі. Вона втікає раніше, ніж свобода $\dddot{1}$ налякає. Нехай неволя в шовках або і в багряниці, на румаках татарських або і на скакунах гордо їздить; нехай собі титулів здобува і ними оздоблюється; нарешті, нехай та сова ястребиться, як хоче, - однак залишиться совою, з орлом ніколи не зрівняється» [7, с. 364, 366].

Свобода розглядається як основа державності, громадяни якої повинні цілком свідомо підходити до виборів державця. При цьому С. Оріховський зазначає: «Король вибирається для держави, а не держава існує задля короля». На цій підставі гадаємо, що держава набагато шляхетніша й достойніша за короля. Закон же, якщо він $є$ душею і розумом держави, значно кращий за непевну державу і вищий за короля. «Отже, якщо тебе запитають, - звертається він у своєму повчанні майбутньому королю Станіславу Августу, - хто ти? - відповідай побожно й правдиво так: я король - вуста, очі й вуха закону, а точніше, інтерпретатор закону, який присягнувся на віру в королівства зміцнювати і нічого іншого не робити, як тільки те, що закон велить» [8, с. 33-34].

Шкода, що ми так погано ознайомлені з досягненнями наших співвітчизників. Неможливо утриматися від того, щоб не навести ще кілька думок, які С. Оріховський висловлює як рекомендації королю. (Спробував би він це зробити в Росії Івана Грозного, який царював саме в ті часи!) Отже, послухаємо мислителя XVI ст.: «Передусім знай, звертається Оріховський до Станіслава-Августа, - що не всяка людина здатна бути при владі, а лише така, що за природою своєю прагне до правди і справедливості. Але й цього недостатньо. Треба, щоб прагнула вона до науки, яка саму людину зробить і правдивою, і справедливою. Так само і природні здібності, хоч би якими були високими, але якщо людина знехтує наукою, нічого не зробить гідного похвали. Але чому не треба слухати тих, хто відраджує вивчати мистецтва, без яких життя є варварським і нікчемним (це стосується всякого правління, а найбільше світської влади)? А тому, що ніхто не зробить нічого корисного навіть у найнезначнішому мистецтві, якщо не буде вчитися» $[8$, c. 27].

I хоч, як підданий Речі Посполитої, Оріховський приділяє увагу саме Польській державності, він ніколи не забуває про те, що він представник Русі. От як він це відзначає, закликаючи керівника держави 
активно включитися до долі українського (руського) народу. «Ти доки живеш у Краківському замку, - закликає Оріховський, - люд у Русі нещасливо гине, та ще й як гине! Цього без сліз і розповісти неможливо: ніхто людей не захищає, ніхто не боронить; міста попалено, фортеці зруйновано; багатьох славних лицарів посічено або забрано в полон; немовлят порубано, літніх повбивано, дівчат згвалтовано прилюдно, жінок збезчещено на очах у чоловіків, молодь пов'язано і забрано разом із реманентом і худобою, так що нема чим і землю обробити. Жах і смуток всюди на полях і в оселях наших... Лише Ян Тарновський, призначений для оборони цього краю полководець, доклав зусиль і в короткий строк зумів зібрати докупи утікаюче військо і заступив шлях ворогові» $[8$, с. 25-26].

Київський біскуп, автор ряду полемічних, моралізаторських, поетичних, політичних творів, Йосип Верещинський накреслив в ряді праць - «Дорога певна до найшвидшого і найнадійнішого осадження в Римському краї пустельних земель рицарства королівства Польського» (1594), «Оголошення про фундування рицарської школи для синів коронних в Україні» (1597), «Голос на піднесення потужної війни проти турецького царя» (1598) - не лише ідею окремої особливої української держави у вигляді князівства, але й вперше розробив план адміністративного устрою цієї держави. Він пропонував розділити землі України на полки, куди входили б населення полкового міста та навколишніх сільськогосподарських угідь. Держава очолювалася князем, військо - гетьманом. Тим самим Верещинський підходить до ідеї автономізму. Над цим задумалися перші українці-католики, достатньо глибоко ознайомлені з європейськими ідеями на тему державності. Так, Себастьяном Кленовичем в поемі «Роксоланія» (1584) відстоюється ідея, як і Яном Домбровським в «Сарматії» (1620) про те, що українці - це окремий етнос, так звані сармати. Симон Пекалід в «Острозькій війні» (1600) шкодуе з того, що між шляхтою та козацтвом існує ряд розбіжностей і протиріч.

Православні ієрархи теж віддають належне становленню ідеї української державності, хоча і Петро Могила (1596-1647), і Іван Вишенський (бл. 1550-1620) підпорядковують цю ідею проголошеним ще раннім християнством ідеям рівності перед Богом, влади церкви над державою. Лише в «Апокрисі» (1598) Христофор Філарет, виступаючи проти абсолютизації світської та духовної влади, закликав до того, що монарх у своїй діяльності повинен спиратися на закони, права і свободу підданих.

Різноманіття програм автономізму об'єднувалося навколо ідеї 
основної цінності соціального буття - цінності особистості як такої.

Слід врахувати і те, що саме особистісний підхід був реалізований серед широких кіл населення, починаючи ще з часів Київської Русі, які були пов'язані взаємними зв'язками як морально-етичного, так і усного правового змісту. Це так звана «копа», або «купа». «Копи» скликалися для вирішення суперечок між сусідами (копа сільського кутка), між членами громади (копа громадян), або ж претензій окремих громад (копа регіону). Члени копного суду керувалися стародавніми звичаями і власною думкою. Розслідування злочинів велось на основі незаперечних фактів і з метою не тільки покарати злочинців, але й захистити громадян від повторення подібного злочину. Досить широко застосовувалася смертна кара через повішення, спалення та четвертування. Така кара присуджувалася за крадіжку коней та іншої худоби, викрадення збіжжя, бджіл, а також за розбій, підпал. Злочинець повинен був відшкодувати збитки, а якщо не міг, то відшкодування падало на громаду. Копні суди були орієнтовані на окремого індивіда, починаючи з того, що кожен повинен був з'являтися на засідання, і кінчаючи особистою відповідальністю за свої вчинки.

Таким чином, ми спостерігаємо різноманіття правових систем в Україні в докозацькі часи, але є те, що їх усіх об'єднує, - це орієнтація на окремого суб'єкта права, вимогливість щодо його вчинків і відповідальність за них. Щоб зрозуміти значення та соціальну роль цієї спрямованості, варто звернутися до порівняння зі становищем цього питання у наших сусідів. «В Московском государстве, - пише знавець російського права М.Ф. Володимирський-Буданов, - уже с XIV (XVXVI) ст. нет никаких следов действия Русской Правды. . Итак, почти вся юридическая жизнь народа предоставлялась в продолжении двух столетий действию обычного права и частной воли, не выраженной в письменной форме закона» [2, с. 223].

Далі він виділяє внутрішній зміст цієї правової системи: «Обстоятельством, серьезно отразившемся на специфике национального правосознания, был коллективизм, как принцип жизни русского (славянского) народа. Общинный строй, переживший десять веков нашей истории, не мог не влиять на формирование общественного и индивидуального сознания, психологии, идеалов и ценностей. Как прямая противоположность европейскому индивидуализму, наш обширный коллективизм препятствовал выделению индивидуальности полнокровного объективного права. Личность была поглощена миром. Общезначимыми являются общинные интересы, а личное право рационально отрицается» $[2$, с. 5$]$. 
Зрештою, це можна зрозуміти, якщо звернутися до шляху створення самої держави, яка до XVI ст. в основному називалася Московією, а фактично лише за Петра I стає Росією, тобто Російською імперією. Як відомо, становлення державності відбувалося досить суперечливо. Розпочинається це, фактично, в тяжкі часи татаро-монгольської навали і можна сказати нерозривно пов'язано з нею. Так, навіть певні правові ідеї незаперечно були взяті саме у монголів. Адже в імперії Чингізхана існував звід законів та уставів - «Яса», або ж «Велика Яса». Під страхом смертної кари вона вводилася як обов'язкове законодавство. Цікава деталь - у «Ясі» відзначалося, про що, на жаль, рідко згадується: «Всіх лікарів, мудреців на завойованих територіях звільняють від будь-яких податків». Цей правовий принцип не ввійшов в російське законодавство і навіть у національну свідомість. Відповідно до цієї самосвідомості, як зазначає великий російсько-американський вчений Г.В. Вернадський в своїй праці «Історія права»: «Імперія Чингізхана заснована була на загальному прикріпленні населення до служби державі. Кожний має своє місце у війську або ділянці податі, і з свого місця він не міг зійти. Цей принцип прикріплення особистості державі пізніше стає основою Московського царства XV-XVII ст. і звичайно московські порядки розвинулися саме на основах, закладених монгольським пануванням» $[1$, с. 5].

«Звідси, - пише Вернадський, - загальним завданням міжнародного права монголів було встановлення всесвітнього панування. Ця мета повинна бути досягнута шляхом або міжнародних переговорів про підкорення інших народів волі Хана, або, при відмові від покорення - шляхом війни» [1, с. 118].

Такі правові установки ніяк не могли відповідати принципу «золотої вольності», який споконвічно був основним змістом праукраїнської та української ментальності, і тому Москва невтомно намагалася його винищити протягом багатьох сторіч.

Найпослідовнішим виразником принципу «золотої вольності» стало українське козацтво, яке створило свою правову традицію. Її основна відмінність - це поєднання різних правових норм, об'єднаних звичаєм. Разом з тим слід відзначити, що козацьке право мало свої непорушні принципи - вірність Україні та її народу; захист батьківщини від ворогів, який з часів Петра Конашевича-Сагайдачного нерозривно злився з принципом оборони православної віри та церкви; взаємоповага та взаємопідтримка товаришів по зброї. До речі слово «товариш» має українське походження і означало «той, що володіє „товаром“, тобто скотиною». 
Всі правові норми спиралися на принцип рівності та рівноправності, в основі якого лежала оцінка не станової приналежності особистості, а її, особистості, неповторні цінності - чесність, моральна гідність і обов'язково - достатньо широке коло тогочасних так би мовити «наукових» знань. Адже ще не знищена була освітня система України, вершиною якої була «людина трьохмовна» - така, яка вільно володіє грецькою, латинською та давньоєврейською мовами, щоб можна було, спираючись на істинний зміст біблійного першоджерела (для чого і була потрібна давньоєврейська мова), вести полеміку як мовною основою православ'я - грецькою, так і мовою тогочасної західноєвропейської культури в цілому - латинською.

Відповідно формується і визначення так би мовити соціальної цінності особистості у поняттях «достойники» та «зверхники». Якщо другі нерідко були пов'язані з владою, в основному ворожою щодо українців (поляки, московити), то перші, незалежно від свого соціального статусу, були завжди шановними і авторитетними людьми.

Це був так би мовити той соціальний грунт, на який і спиралося козацтво. Досить поширеним є намагання звести козацтво до західноєвропейського лицарства, але, на наш погляд, це не відповідає дійсності. Адже головним принципом лицарів Західної Європи була повна і безумовна покірність волі сеньйора (згадаймо славнозвісний французький епос «Пісня про Роланда», де васал не роздумуючи кидається виконувати будь-яку вимогу свого господаря, іноді безчесну і аморальну). Правилом же козацтва було самостійне виконання своїх військових обов'язків і якщо керівник - полковник, гетьман відступали від головних принципів захисників народу, то це викликало активну протидію. Особливо що, на наш погляд, варто виділити - це те, що на теренах Європи, та й світу в цілому раніше всіх інших народів реалізується принцип, який лише через півтори сотні років стає провідним у Французькій буржуазній революції-принцип рівності.

Цьому сприяв ряд обставин. В першу чергу те, що ментальність українців споконвіку біла суб'єктивно-індивідуалістичною. Значну роль відіграла і та обставина, що не склалося станового суспільства: і оцінка суспільства, і оцінка особистості визначалася не становими характеристиками, а загальнонаціональними.

Не останню роль зіграла і та обставина, що Україна до злощасної Переяславської ради була нерозривно пов'язана з європейською культурою та наукою. А, як відомо, саме в XVI-XVII ст. в європейській філософії ряд мислителів підійшли до проблем соціальної рівності. Не вдаючись до аналізу складного процесу, який пройшла ідея рівності, 
варто відзначити, що починаючи з євангельського проголошення цієї ідеї через Гоббсівське ствердження вічної боротьби в суспільному бутті («Левіафан»), пошуки Локком дієвого механізму рівності і, нарешті, в XVIII ст. розроблені практичні шляхи досягнення рівності. Всі ці ідеї були нерозривно пов'язані з соціальними переворотами, починаючи зі знищення влади аристократії в Англійській буржуазній революції XVII ст., і завершуючи проголошенням свободи та рівності в лозунгах Французької буржуазної революції: «Свобода, рівність, братерство».

Ці омріяні в Європі ідеали були достатньою мірою реалізовані в діяльності козацтва України і, що особливо цінно і важливо, вони змогли підготувати появу правового законодавства, де враховано те, що стає змістом сучасної філософії і культури - поліфонізм людської сутності та її неповторність.

Це законодавство створено генієм Пилипа Орлика (1672-1743) в Конституції 1710 р. Спадкоємець баронського чеського роду, який отримав блискучу освіту в Європі, знавець ряду мов, в тому числі шведської та французької, з 29 років стає не тільки генеральним писарем при гетьмані I. Мазепі, але й найщирішим послідовником ідеї гетьмана про створення єдиної, неподільної, суверенної України. Обраний гетьманом після смерті Мазепи, він до кінця свого життя намагався втілити цю ідею не тільки в практичній діяльності, але й у філософсько-правових працях - «Вивід прав України», «Діаруш», і переписці, досі ще недоступній українським дослідникам, бо знаходяться в різних архівних сховищах Польщі, Франції, Швеції, Туреччини.

Крім козацьких правових ідей, втілених в документах Запорізької Січі, які до речі і досі не повернуті Україні і перебувають в архівах Санкт-Петербурга, значну роль відіграли так звані «Гадяцькі статті», фактичним автором яких був Юрій Немирич (1612-1649), який прожив всього лише 47 років, але обгрунтував ідею самостійності України в складі федерації з Польщею та Литвою. Усі три частини федерації за Гадяцькою угодою обирали короля, сейм і виступали спільно проти зовнішніх ворогів. Самостійність української держави визначалася тим, що вищим державним органом проголошувалися Національні збори (виборний парламент), держава мала право карбувати свої гроші, утримувати реєстрове військо в 60 тис., право на наймане військо до 10 тис., організацію освіти - «Гімназії, колегії, школи і друкарні, скільки їх буде потрібно, буде вільно ставити, свободно в них науки відправляти і деякі книги друкувати про релігійні контраверсії [3, с. 26]. Москва не залишилася осторонь. Вона активно поширювала чутки про те, що Виговський запродався полякам. Зібравши 100- 
тисячне військо в 1659 р. під командуванням князів Олексія Трубецького, Григорія Ромадановського та Семена Пожарського, московські війська перейшли кордон України і почали спустошувати міста та села. Виговський завдав нищівного удару, де на полі бою залишилося 50 тисяч московитів - знаменита Конотопська битва. Як писав відомий російський історик Сергій Соловйов: «Краса і гордість московської кінноти [...] зникла в один день... Ніколи вже цар московський не зміг вивести в поле значне військо. В жалобному одязі вийшов Олексій Михайлович до народу, і жах охопив Москву... Після здобуття стількох міст, після захоплення литовської столиці Москва затремтіла за власну безпеку». I все ж в Гадяцьких угодах, які, на жаль, так і не були прийняті, була достатньо послідовно сформульована ідея парламентарної республіки, основою якої, за висновком Ю. Немирича, була концепція свободи. Виступаючи у Варшаві як канцлер Великого Князівства Руського в 1659 р., він проголошує: «Ми народжені у свободі, виховані у свободі і як вільні люди нині повертаємося до неї. I готові умирати за неї $[. .$.$] разом з усією нашою вітчизною. Вона [свобода -$ A.Б.] була нашою спонукою, цей грунт, який не розірвали ні відмінність у мовах, ні навіть релігія» [4, с. 212].

Парламентарно-республіканські ідеї, розпочаті в Гадяцьких угодах Ю. Немиричем, були реалізовані в Конституції Пилипа Орлика. В доповіді на Світовому конгресі 19 жовтня 1992 р., присвяченому обговоренню нової конституції, американський суддя українського походження Богдан Футей відзначав: «Україна має своє власне рідне джерело, з котрого повинна черпати основні ідеї правової держави. Цим джерелом є Конституція гетьмана Пилипа Орлика. Цей юридичний документ є не лише великим юридичним досягненням, а й доказом політичної зрілості того часу. Конституція Пилипа Орлика 1710 року, написана майже за 80 років до Конституції США, мала такі демократичні основи, як розподіл влади, приватна власність та незалежний судовий трибунал, як основні засади для існування тодішньої козацької держави... Можна сказати, що Джеймс Медісон, батько Конституції США, користувався тими самими демократичними засадами Гетьмана Пилипа Орлика» [14, с. 10].

Вся Конституція мала дві частини: декларативну та власне договір, який складався з 16 пунктів. В першу чергу слід відзначити глибокий демократизм, який відображений не тільки в принципі виборності, але й в такому показовому факті, що спеціально виділена стаття про обмеження сваволі владних осіб, в тому числі і гетьманату: «Ясновельможному Гетьману виділяється (частина) із спільних володінь i 
земель Війська Запорізького, але так, щоб необмежена влада не порушила прав тих, чиї заслуги перед батьківщиною менші, а саме: ченців, священників, виборних і рядових козаків, двірських слуг і приватних осіб... А панам полковникам жодним способом не слід втручатися [в справи - А.Б.] полкової скарбниці, оскільки їм належить задовольнятися прибутками й пільгами уряду» [10, с. 40].

Жаль, що наша сучасна «правляча еліта» не знаходить часу для ознайомлення з цінностями власної культури. Може вона б усвідомила той факт, що за 300 років до наших днів саме в Україні вперше в світі була обгрунтована ідея послідовного демократизму.

Вся Конституція пронизана проблемами національної ідентичності. Провідною серед цих проблем стає ідея національної самобутності, яку Орлик розпочинає з пошуків так би мовити концепції генетичного походження українців. В преамбулі він розгортає цю проблему, спираючись на достатньо поширену в Європі ідею сарматизму, яка, в свою чергу, завершується у нього так званою хазарською теорією, що і стає обгрунтуванням неповторності козацької державності.

При цьому жодною мірою не проголошується яка б то не була зверхність щодо інших народів. Навпаки, досить дружньо закликається до спілки з татарами, як найближчими сусідами і навіть зі шведами: «Оскільки ще своє походження колишнє хазарське плем'я, назване згодом козацьким, веде і виводить від відважних і непереможних готів» $[10$, c. 36$]$.

Загальне спрямування Конституції орієнтовано на вічні цінності ментального спрямування українців: на свободу і особистісну неповторність. Жаль, що знаменитий автор «Демократіі» Шарль Алексіс де Токвіль, який в XIX ст. чітко визначив відмінність американської демократії від західноєвропейської - американці «не стають рівними, вони народжуються рівними» $[10$, с. 8$]$, не був знайомий з Конституцією Орлика. Адже ідея «вродженої демократії», підкріплена правовим принципом виборності, зафіксована раніше інших народів саме на сторінках цієї Конституції. Орлик достатньо грунтовно зупиняється на тих помилкових кроках, які привели український народ до втрати самостійності та незалежності. От як це звучить в преамбулі Конституції: «Народ козацький, що досі перебував під тяжким польським ярмом, прагнучи відновити колишню свободу, повстав за ревну віру православну, за закони батьківщини і старі вольності під проводом палкого борця, найвідважнішого керманича вічної пам'яті Богдана Хмельницького [...] і цілком добровільно піддав і себе, і народ Царству Московському, сподіваючись на те, що вони, будучи такого 
ж обряду, як і ми, дотримуватимуться своїх зобов'язань відповідно до прийнятих пактів і конституцій, скріплених присягою і що він назавжди збереже Військо Запорозьке і вільний народ Руський під його покровительством при непорушних правах законів і вольностей. Однак після смерті вищеназваного Гетьмана Богдана Хмельницького, який благочестиво почив, Московське царство взяло намір, дошукуючись багатьох засобів і способів, позбавити Військо Запорозьке його вольностей, підтверджених власною присягою, призвести його до остаточного знищення і накласти рабське ярмо на вільний народ, який ніколи не дозволяв завойовати силою зброї. Нарешті, тепер уже недавно, за часів ясновельможного Гетьмана Івана Мазепи, що благочестиво почив, вищеназване Царство Московське прагнучи втілити свої нечестиві за допомогою сили і платячи нам злом за добро, замість вдячності і справедливої шани за таку велику і вірну службу, за (наші) військові видатки, що довели нас до повного розорення, за незчисленні героїчні подвиги і криваві ратні труди, вирішило перетворити козаків на регулярну армію, підкорити своїй владі міста, відмінити права і вольності, знищити з коренем Військо Запорозьке, що перебуває в пониззях Дніпра, і навіть стерти його ім'я» [10, с. 34].

Саме на сторінках Конституції відтворені нові ментальні особливості української самосвідомості. В першу чергу - це усвідомлення себе окремим народом, що чітко спрямовано до визначення своєї неповторної специфіки. Її основним змістом є утвердження цінності кожного людського буття як такого. Звідси - гостре неприйняття протилежних і чужих щодо цього принципів, дій, звичаїв. Так, якщо виборна система спирається на оцінку самої особистості, то успадкована влада - лише на «едність крові». Цікаво в цьому відношенні звернутися до характеристик так би мовити незацікавлених людей-іноземців. Так, Жан Балюз, французький дипломат, який перебував в Батурині в 1704 р., пише про Мазепу: «Він дуже поважаний у козацькій країні, де народ, загалом свободолюбивий і гордий, мало любить тих, що ним володіють. Привернув Мазепа козаків до себе твердою владою, великою воєнною відвагою... Розмова з цим володарем дуже приємна, він має великий досвід у політиці й, у протилежність до московців, слідкує і знає, що діється в чужих країнах. Він показував мені свою збірку зброї, одну з найкращих, що я бачив у житті, а також добірну бібліотеку, де на кожному кроці видно латинські книжки» [11, с. 124]. Відомий мандрівник Й.Г. Корба, характеризуючи тогочасні традиції Москви, відзначає в книжці, виданій у Відні в 1700 р.: «У жовнірів Московії є у звичці жорстоко і зовсім самовільно, без поваги до осіб або обставин, бити 
затриманих п'ястком, рушницею і палицями [...] московити не мають почуття гідності, неосвічені, мають в'ялий і тупий розум. В проханні до царя московини підписуються зменшеними іменами, наприклад Яків - ,Якуша“, конче додаючи при цьому „холоп“" i „подлейший и презренный раб“» $[12$, с. 38$]$. А данський посол Юля Юст, який перебував в Росії та Україні в 1709-1711 рр., зазначає: «У Московщині закон оминають на кожному кроці. У всьому (коли когось притягли до суду) можна було зрештою відкупитися, даючи Меншикову „взятку“ 10 , 20, чи 30 рублів. При чім з того цар (Петро Великий) дістає „свою частину“. Зрештою, що можна очікувати кращого в країні, де вищі достойники постійно повторюють, нехай цілий світ говорить, що хоче, а ми все-таки будемо робити по-своєму» [11, с. 44].

Можна сміливо стверджувати, що на початку XVIII ст. українська національна самосвідомість, завдяки глибокому вкоріненню як у західну, так і у східні культури, виробляе демократично-правові норми, які полюсово протилежні самодержавно-деспотичним державницьким ментальним підвалинам московської духовності. На жаль, уже до кінця XVIII ст. відбувається процес значної втрати цих відмінностей. I одним із шляхів знищення демократичних установок української ідентичності було знищення правових українських систем. I хоч ще за Єлизавети було запропоновано створення «Прав, по которым судится малороссийский народ», наприкінці XVIII ст. разом зі скасуванням Гетьманщини та автономії України припинило остаточно офіційне застосування «Прав» і разом з тим проведено було уніфікацію правових норм Російської імперї в цілому.

Відроджуючи національну ідентичність, необхідно повернутися до процесу, який був перерваний на початку XVIII ст. і втілений в найпрогресивнішому правовому документі-Конституції Пилипа Орлика. I хоч діяла вона недовго - десь близько чотирьох років, але цей документ є свідченням високого рівня демократичних принципів самосвідомості українського народу. Тому, на наш погляд, відроджуючи самобутність України, необхідно приділити значну увагу дослідженню тих ідей, які були відтворені на сторінках Конституції. А це можна зробити, тільки зібравши розкидані по всьому світові праці П. Орлика, дивовижного борця за національну державність, який присвятив цьому все своє життя.

На жаль, ще недостатньо народ України знає своїх героїв, які віддали життя не за чужу, а за свою вітчизну. Варто цьому повчитися хоча б у наших сусідів поляків. Незважаючи на те, що їхня Конституція, яка була прийнята через 79 років після Конституції Пилипа Орлика 
в 1789 р. і проіснувала всього лише 4 роки, все ж вони відзначають $\dddot{1}$ прийняття як всенародне свято. Тим більше факт документально-правового визначення національної ідентичності, яким і була Конституція Пилипа Орлика - цей величезний пам'ятник самій ранній демократії у світі, не може не бути загальнонаціональним святом.

\section{Бібліографія}

[1] Вернадский Г.В. История права. - СПб: Лань, 1999.

[2] Владимирский-Буданов М.Ф. Обзор истории руского права. - Ростов-на-Дону: Феникс, 1995.

[3] Гадяцький трактат // Історія української Конституції. - К.: Право, 1993.

[4] Золоте слово. Хрестоматія літератури України епохи середньовіччя. Література високого середньовіччя /988-1240/. - К.: Раконті, 2000.

[5] Кістяковсъкий О.Ф. Источники, из которых составлен свод // Антологія української юридичної думки. - К.: Юридична думка, 2002. - T. 3 .

[6] Манан П. Інтелектуальна історія лібералізму. - К.: Дух і літера, 2005.

[7] Оріховсъкий $C m$. Квінкунс, тобто взірець устрою Польської держави // Українські гуманісти епохи Відродження. Антологія у 2х частинах. Ч. I. - К.: Наукова думка, Основи, 1995.

[8] Оріховсъкий $\mathrm{Cm}$. Напучення польському королю Станіславу Августу // Там само.

[9] Пакти й Конституції законів та вольностей війська запорозького. - К.: Право, 1997.

[10] Покровский M.M. Русская история в самом сжатом очерке. Части I и II. - М.: Учпедгиз, 1934.

[11] Січинсъкий В. Чужинці про Україну. - Львів: Слово, 1991.

[12] Січинсъкий В. Чужинці про Україну. - К.: Довіра, 1992. 
[13] Яковенко Н. Нарис історії України з найдавніших часів до кінця XVIII ст. - К.: Генеза, 1997.

[14] Футей Б. Становлення правової держави в Україні: 19912003 pp. - K.: Юрінком Інтер, 2005.

Надійшла до редакиї̈ 2 березня 2011 р. 